\title{
Deep Hemangioma
}

National Cancer Institute

\section{Source}

National Cancer Institute. Deep Hemangioma. NCI Thesaurus. Code C6555.

A hemangioma arising from the deep soft tissues. 